\title{
A Comparative Cradle-to-Gate Life Cycle Assessment of Mid-Rise Office Building Construction Alternatives: Laminated Timber or Reinforced Concrete
}

\author{
Adam B. Robertson ${ }^{1, *}$, Frank C. F. Lam ${ }^{2}$ and Raymond J. Cole ${ }^{3}$
}

1 Canadian Wood Council, 400-99 Bank Street, Ottawa, ON K1P 6B9, Canada

2 Department of Wood Science, Faculty of Forestry, University of British Columbia, 2424 Main Mall, Vancouver, BC V6T 1Z4, Canada; E-Mail: frank.lam@ubc.ca

3 School of Architecture and Landscape Architecture, University of British Columbia, 6333 Memorial Road, Vancouver, BC V6T 1Z2, Canada; E-Mail: rcole@sala.ubc.ca

* Author to whom correspondence should be addressed; E-Mail: adam.robertson@alumni.ubc.ca; Tel.: +1-613-747-5544; Fax: +1-613-747-6264.

Received: 23 April 2012; in revised form: 25 June 2012 / Accepted: 26 June 2012 /

Published: 17 July 2012

\begin{abstract}
The objective of this project was to quantify and compare the environmental impacts associated with alternative designs for a typical North American mid-rise office building. Two scenarios were considered; a traditional cast-in-place, reinforced concrete frame and a laminated timber hybrid design, which utilized engineered wood products (cross-laminated timber (CLT) and glulam). The boundary of the quantitative analysis was cradle-to-construction site gate and encompassed the structural support system and the building enclosure. Floor plans, elevations, material quantities, and structural loads associated with a five-storey concrete-framed building design were obtained from issued-for-construction drawings. A functionally equivalent, laminated timber hybrid design was conceived, based on Canadian Building Code requirements. Design values for locally produced CLT panels were established from in-house material testing. Primary data collected from a pilot-scale manufacturing facility was used to develop the life cycle inventory for CLT, whereas secondary sources were referenced for other construction materials. The TRACI characterization methodology was employed to translate inventory flows into impact indicators. The results indicated that the laminated timber building design offered a lower environmental impact in 10 of 11 assessment categories. The cradle-to-gate process energy was found to be nearly identical in both design scenarios $\left(3.5 \mathrm{GJ} / \mathrm{m}^{2}\right)$, whereas the cumulative embodied energy (feedstock plus process) of construction materials was estimated to be 8.2 and
\end{abstract}


4.6 $\mathrm{GJ} / \mathrm{m}^{2}$ for the timber and concrete designs, respectively; which indicated an increased availability of readily accessible potential energy stored within the building materials of the timber alternative.

Keywords: whole building life cycle assessment; cradle-to-gate; material selection; wood products; glulam; cross-laminated timber; reinforced concrete; mid-rise office building; embodied energy

\section{Introduction}

The construction and operation of buildings are responsible for the consumption of up to $40 \%$ of global energy use, as well, at least one third of the anthropogenic greenhouse gas (GHG) emissions in developed and developing countries can be related to activities in the building and construction sectors of the economy [1]. This will be further exacerbated as the world's population continues to increase; requiring more buildings for society to live and work. Analyzing, quantifying, interpreting, and comparing the environmental impacts that contemporary building design alternatives afflict on the natural environment, including their role in contributing to global climate change and environmental degradation is a primary motivation behind this research.

Presently, the Pacific Northwest and Western Canada in particular, are experiencing the worst mountain pine beetle (MPB) outbreak in recorded history. This ecosystem altering epidemic is causing widespread mortality of the lodgepole pine forests, the most abundant commercial tree species in the region. The bark beetle has also migrated south into the United States and eastward, posing a significant threat to the jack pine stands of Canada's northern boreal forest [2]. Due to the severity of the current MPB attack, there is a surplus of infected, unused lodgepole pine and standing dead wood. The volume of MPB attacked trees is enormous; approximately 620 million cubic metres with the MPB epidemic expected to kill one billion cubic meters of B.C. timber before it subsides [3]. Over the last five years, the excessive volume of rotting dead fall, resulting from MPB killed timber, has resulted in Western Canada's forests becoming net emitters of GHGs [4]. The quest to develop feasible, economically viable, and environmentally responsible solutions to mitigate the effect of the MPB epidemic is at the forefront of government policy. Amongst the proposed solutions for the use of MPB-killed wood fibre are innovative, value-added, engineered wood products (EWPs), which have become a primary focal point for research, development, and implementation in non-residential building markets.

In North America, the mid-rise, non-residential building sector is currently dominated by the use of reinforced concrete and wide flange steel as the primary structural support systems. The advancement in understanding of timber building behaviour, along with the refinement of EWP design and performance has demonstrated the applicability of using wood as a primary structural support system in mid-rise building construction. In 2009, the Canadian Province of British Columbia amended their Building Code to permit the design and construction of wood-framed buildings up to six-storeys in height [5]. The previous height restriction for wood-frame structures was four-storeys. This research 
project considered these building code changes as an impetus for examining the environmental impact of different mid-rise building construction scenarios.

Presently, there are concerted efforts being made throughout Canadian government agencies to promote the use of domestic timber products and wood construction systems in publicly funded buildings. The research presented in this paper aimed to obtain additional quantitative measurements about the environmental advantages and disadvantages of wood building construction compared with other material choices. This information can be used to support government officials, designers, and builders, in making informed choices regarding the environmental impacts of construction material selection during building design and development.

\section{Methodological Framework}

Discovery Place-Building 12 was selected as a case study example, due to its design, use, location, and construction system. Discovery Place is a 14,233 $\mathrm{m}^{2}$ office building, which was constructed in 2009 in Burnaby, British Columbia, Canada. The non-residential occupancy of the building was a factor in its selection, along with the building's location (Pacific Northwest), height of five-storeys with three levels of underground parking and its reinforced concrete structural frame, which was perceived as typical industry practice for a building of this type and size.

The LCA comparison of alternative design scenarios for Discovery Place-Building 12 was tailored to be focused on two main systems; the primary structural support systems (cast-in-place reinforced concrete or glulam/CLT) and the building enclosure system. Limiting the scope of the environmental analysis to these building systems permitted the research to focus on the two building elements that are responsible for 60 to $90 \%$ of the total embodied environmental impacts of commercial office buildings [6,7] and resulted in a reduction of inventory data collection and aggregation.

In order to perform an environmental comparison of two alternative construction scenarios for Discovery Place-Building 12, it was necessary to redesign the case study concrete-framed building using timber elements. The goal was not to perform a direct material replacement or substitution, but to redesign a functionally equivalent structural system and building envelope, by choosing EWPs and dimensional lumber where a feasible option existed. In almost all instances, the footprints, floor-to-floor heights, and overall building dimensions in both design scenarios were identical or varied by only a few centimetres. At the time this study was conducted, the concept of designing and constructing large footprint, mid-rise office buildings, using heavy timber and CLT structural frames was not typical industry practice in Canada. However, the redesign of Discovery Place-Building 12, using a combination of glulam and CLT for the vertical and horizontal force resisting systems, in conjunction with reinforced concrete, was considered a feasible solution based on the examples that were erected or in design development throughout North America and the European Union.

Using the plan and elevation layouts of the original concrete building, a redesigned, functionally equivalent hybrid laminated timber-framed alternative was conceived. The heavy timber-framed design utilized glued-laminated timber beams and columns, cross-laminated timber floor and roof plates, with reinforced concrete used for the below-grade foundations, parking level slabs, above- and below-grade elevator/stair cores and primary shear walls. A graphical depiction of glulam columns and 
beams supporting a CLT floor plate, along with a hybrid timber-concrete frame is shown as Figure 1(a,b), respectively.

Figure 1. (a) Glulam beam and column frame with cross-laminated timber (CLT) floor [8];

(b) Glulam frame with concrete shear core [9].

(a)

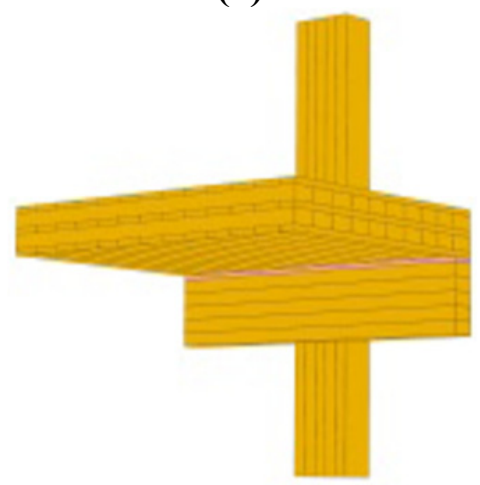

(b)

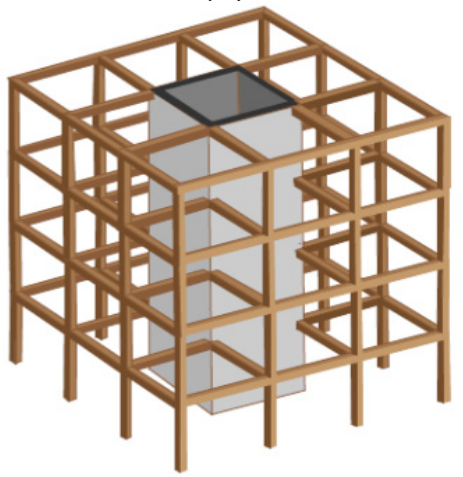

In order to maintain functionally equivalency of both the concrete and timber building designs, it was necessary to ensure the timber building enclosure (roof, exterior walls, and curtain wall) had the same thermal resistance (RSI) values as the concrete building. Having consistent RSI values for the building enclosure in both the concrete- and timber-framed designs provided a proximate estimate that over each building's life cycle, the operational energy use would be equivalent in either design alternative.

After the structural and building enclosure designs were completed and equivalent structural capacity and envelope thermal resistance values were verified, a bill of materials was calculated for both the concrete- and laminated timber-framed design alternatives. This bill of construction materials was used to evaluate the environmental impact of each design scenario using the life cycle assessment (LCA) methodology. The system boundary of the comparative LCA study was cradle-to-gate, considering a 50-year building lifetime horizon. The environmental burdens associated with each building product were considered from raw materials acquisition, through the manufacture/processing stages, accounting for the production and use of fuels, electricity, and heat, as well as taking into account transportation/distribution impacts at all points along the product supply chain. The boundaries of the quantitative study began at the raw materials extraction and finished at the entrance to the construction site gate, with the inclusion of building material and component replacement over the course of the 50-year building life cycle. A combination of publicly available North American databases $\left(\right.$ BEES $^{\circledR}$ 4.0, ATHENA $^{\circledR}$ EcoCalculator, and the US LCI Database) as well as on-site, factory measurements were used to account for the material, energy, and emissions flows that occurred throughout the raw material acquisition, manufacturing, and transportation phases of each building product's life cycle (Appendix A). The North American specific environmental profile of CLT was developed using multiple data sources, including on-site measurements from a pilot manufacturing facility located in New Westminster, British Columbia, Canada [10]. The environmental impacts of both the concrete and laminated timber building design alternatives were compared under 11 impact categories and characterized using the U.S. Environmental Protection Agency's TRACI methodology [11]. 
Although the quantitative study boundary was cradle-to-gate, a qualitative analysis and review was performed to explore the implications of considering other life cycle stages (on-site construction/erection and end-of-life), as per Table 1.

Table 1. Quantitative vs. qualitative analyses of life cycle stages.

\section{Quantitative}

(numerically defined within study)

- Raw materials extraction

- Manufacturing and processing

- Intermediary transportation effects associated with cradle-to-construction site gate life cycle stages

\section{Qualitative}

(discussed based on case study $\&$ literature reviews)

- On-site building construction and erection

- Transportation associated with on-site construction

- End-of-life (demolition and disposal) choices for building materials, including reuse, recycling, reprocessing, energy recovery, and landfill

\section{Study Limitations}

This LCA study is limited by its geographic and temporal scales. The relevance of the results and conclusions that are drawn from this work cannot be applied unilaterally to other geographic regions, building types or time periods. The findings of this LCA study are based on a steady-state analysis assumption; a snapshot in time. Reality, on the other hand, is ever changing; as design considerations, industrial processes, and environmental emissions and effects follow dynamic patterns and will continually transform throughout time. Although these results can be used to postulate environmental impact comparisons for other similar buildings, the detailed results shown are directly applicable only to this one case study example; Discovery Place-Building 12, and are valid for design, construction, and materials production processes that have taken place in the last $10-15$ years.

\section{Results}

\subsection{Functional Units and Bill of Materials}

This LCA study focused only on the direct and indirect environmental impacts of the structural and building enclosure (envelope) systems. The building materials and their corresponding functional units that were considered in the comparison of the concrete- and heavy timber-framed designs are presented in Table 2, as follows:

Table 2. Building materials and their corresponding functional units.

\begin{tabular}{llll}
\hline Concrete design & Timber design & Functional unit & Notes \& assumptions \\
$\begin{array}{l}\text { Gypsum Wall } \\
\text { Board }\end{array}$ & Gypsum Wall Board & $0.09 \mathrm{~m}^{2}\left(1 \mathrm{ft}^{2}\right)$ & $\begin{array}{l}13 \mathrm{~mm}(1 / 2 ”) \text { thick, includes tape, mud, } \\
\text { screws @ 406 mm (16”) O/C studs, } \\
\text { corner bead is not included }\end{array}$ \\
\hline Steel Stud Framing & - & $0.09 \mathrm{~m}^{2}\left(1 \mathrm{ft}^{2}\right)$ & $\begin{array}{l}33 \mathrm{~mm} \text { galvanized studs @ 610 mm (24”) } \\
\mathrm{O} / \mathrm{C}, \text { screws included }\end{array}$ \\
\hline & Wood Stud Framing & $0.09 \mathrm{~m}^{2}\left(1 \mathrm{ft}^{2}\right)$ & $\begin{array}{l}38 \times 89 \mathrm{~mm}(2 ” 4 ” \text { nominal }) \text {, untreated, } \\
\text { kiln-dried @ 406 mm (16") O/C, } \\
\text { galvanized steel nails included }\end{array}$ \\
\hline
\end{tabular}


Table 2. Cont.

\begin{tabular}{|c|c|c|c|}
\hline Concrete design & Timber design & Functional unit & Notes \& assumptions \\
\hline- & $\begin{array}{l}\text { BioPreserve Soyguard } \\
\text { Wood Sealer }\end{array}$ & $9.29 \mathrm{~m}^{2}\left(100 \mathrm{ft}^{2}\right)$ & $\begin{array}{l}\text { Applied to exterior exposed wood } \\
\text { only, repeated every } 2 \text { years }\end{array}$ \\
\hline $\begin{array}{l}\text { Anonymous R-13 } \\
\text { Insulation }\end{array}$ & $\begin{array}{l}\text { Anonymous R-13 } \\
\text { Insulation }\end{array}$ & $0.09 \mathrm{~m}^{2}\left(1 \mathrm{ft}^{2}\right)$ & $89 \mathrm{~mm}(3-1 / 2)$ thick \\
\hline $\begin{array}{l}\text { Spray Foam } \\
\text { Insulation }\end{array}$ & - & $1 \mathrm{~m}^{2}$ & $\begin{array}{l}3 \mathrm{~cm} \text { thick, closed cell polyurethane } \\
\text { with } \mathrm{H}_{2} \mathrm{O} / \mathrm{CO}_{2} \text { blowing agent }\end{array}$ \\
\hline Slab-on-Grade * & Slab-on-Grade * & $0.09 \mathrm{~m}^{2}\left(1 \mathrm{ft}^{2}\right)$ & $\begin{array}{l}102 \mathrm{~mm}(4 ") \text { thick, } \mathrm{f}^{\prime} \mathrm{c}=21 \mathrm{MPa}, 15 \% \\
\& 20 \% \text { fly ash cement mixes } \\
\text { considered, assumed } 0.908 \mathrm{~kg} / \mathrm{m}^{2} \\
\left(1.67 \mathrm{lbs} / \mathrm{yd}^{2}\right) \text { of reinforcing steel }\end{array}$ \\
\hline $\begin{array}{l}\text { Below-Grade } \\
\text { Foundation Walls \& } \\
\text { Spread Footings * }\end{array}$ & $\begin{array}{l}\text { Below-Grade } \\
\text { Foundation Walls \& } \\
\text { Spread Footings * }\end{array}$ & $0.09 \mathrm{~m}^{2}\left(1 \mathrm{ft}^{2}\right)$ & $\begin{array}{l}203 \mathrm{~mm}(8 ") \text { thick, f'c }=21 \mathrm{MPa}, 15 \% \\
\& 20 \% \text { fly ash cement mixes } \\
\text { considered, assumed } 23.9 \mathrm{~kg} / \mathrm{m}^{2}(44 \\
\left.l \mathrm{bs} / \mathrm{yd}^{2}\right) \text { of reinforcing steel }\end{array}$ \\
\hline $\begin{array}{l}\text { Above-Grade } \\
\text { Walls, Beams, } \\
\text { Slabs, } \\
\text { Drop Panels \& } \\
\text { Slab Bands * }\end{array}$ & - & $0.0283 \mathrm{~m}^{3}\left(1 \mathrm{ft}^{3}\right)$ & $\begin{array}{l}\mathrm{f}^{\prime} \mathrm{c}=28 \mathrm{MPa}, 15 \% \& 20 \% \text { fly ash } \\
\text { cement mixes considered, average of } \\
86.2 \mathrm{~kg} / \mathrm{m}^{3}\left(145 \mathrm{lbs} / \mathrm{yd}^{3}\right) \text { of reinforcing } \\
\text { steel assumed }\end{array}$ \\
\hline $\begin{array}{l}\text { Columns \& Shear } \\
\text { Cores/Walls * }\end{array}$ & $\begin{array}{l}\text { Elevator \& Stair Concrete } \\
\text { Shear Cores/Walls * }\end{array}$ & $0.0283 \mathrm{~m}^{3}\left(1 \mathrm{ft}^{3}\right)$ & $\begin{array}{l}\mathrm{f}^{\prime} \mathrm{c}=34 \mathrm{MPa}, 15 \% \& 20 \% \text { fly ash } \\
\text { cement mixes considered, average of } \\
172.4 \mathrm{~kg} / \mathrm{m}^{3}\left(290 \mathrm{lbs} / \mathrm{yd}^{3}\right) \text { of } \\
\text { reinforcing steel assumed }\end{array}$ \\
\hline- & $\begin{array}{l}\text { Cross-Laminated Timber } \\
\text { Walls \& Floors }\end{array}$ & $1 \mathrm{~m}^{3}$ & $\begin{array}{l}38 \times 140 \mathrm{~mm}(2 " \times 6 " \text { nominal }) \\
\text { untreated, kiln-dried, MPB-killed } \\
\text { lodgepole pine lumber, bonding } \\
\text { adhesives are included }\end{array}$ \\
\hline- & $\begin{array}{l}\text { Glulam Beams \& } \\
\text { Columns }\end{array}$ & $1 \mathrm{~m}^{3}$ & $\begin{array}{l}\text { Standard grades and dimensions, } \\
\text { untreated, kiln-dried, MPB-killed } \\
\text { lodgepole pine lumber, bonding } \\
\text { adhesives are included }\end{array}$ \\
\hline Curtain Wall & Curtain Wall & $1 \mathrm{~m}^{2}$ & $\begin{array}{l}\text { Viewable \& spandrel glazing } \\
\text { considered, viewable units assumed } \\
\text { double-glazed, low-e, argon gas filled }\end{array}$ \\
\hline- & Generic Cedar Siding & $0.09 \mathrm{~m}^{2}\left(1 \mathrm{ft}^{2}\right)$ & $\begin{array}{l}\text { Bevelled, } 13 \mathrm{~mm}(1 / 2 \text { - can be changed } \\
\text { to } 0.5 \text { if required") thick, } 150 \mathrm{~mm}(6 ") \\
\text { wide, galvanized nails @ } 41 \mathrm{~cm}(16 ") \\
\text { O/C, } 1 \text { coat primer \& } 2 \text { coats stain } \\
\text { (stain reapplied every } \\
10 \text { years) }\end{array}$ \\
\hline
\end{tabular}

* Impacts associated with temporary formwork/falsework for cast-in-place concrete are considered as per [12].

In order to facilitate the comparison of the reinforced concrete and laminated timber design alternatives of Discovery Place-Building 12, it was necessary to perform a quantities take-off of the 
building materials that were contained in each design option. Table 3 shows the approximate material quantities that were required to produce functionally equivalent building systems, constructed out of either reinforced concrete or a combination of concrete and timber products. The concrete and timber building designs both meet the requirements set out by the applicable Canadian structural design codes and guidelines. Thermal equivalency was also maintained, as the heat resistance values of the building enclosures in each design case varied by less than $1 \%$.

Table 3. Material quantities comparison (based on a 50-year building lifetime).

\begin{tabular}{llll}
\hline Material group & Unit of measurement & Concrete design & Timber design \\
\hline Foundation & & & \\
Footings & $\left(\mathrm{m}^{3}\right.$ of concrete $)$ & 1,408 & 1,408 \\
Slab-on-grade & $\left(\mathrm{m}^{3}\right.$ of concrete $)$ & 416 & 416 \\
Foundation walls & $\left(\mathrm{m}^{3}\right.$ of concrete $)$ & 834 & 834 \\
Below-grade columns & $\left(\mathrm{m}^{3}\right.$ of concrete $)$ & 151 & 151 \\
P2, P1 \& ground floor slabs & $\left(\mathrm{m}^{3}\right.$ of concrete $)$ & 3,253 & 3,253 \\
Superstructure & & & \\
Primary shear walls \& cores & $\left(\mathrm{m}^{3}\right.$ of concrete $)$ & 1,293 & 1,293 \\
Vertical load-bearing walls & $\left(\mathrm{m}^{3}\right.$ of concrete or CLT $)$ & 181 & 128 \\
Above-grade floors \& roof & $\left(\mathrm{m}^{3}\right.$ of concrete or CLT $)$ & 3,628 & 2,950 \\
Above-grade columns & $\left(\mathrm{m}^{3}\right.$ of concrete or glulam $)$ & 268 & 122 \\
Beams \& roof parapet & $\left(\mathrm{m}^{3}\right.$ of concrete or glulam $)$ & 166 & 947 \\
Wood sealer & $\left(\mathrm{m}^{2}\right)$ & - & 1,586 \\
Building Enclosure & & & \\
Curtain wall & $\left(\mathrm{m}^{2}\right)$ & 2,415 & 2,415 \\
Cedar siding & $\left(\mathrm{m}^{2}\right.$ of 13 mm thickness $)$ & - & 13,374 \\
ccSPF insulation & $\left(\mathrm{m}^{3}\right)$ & 2,134 & - \\
Building Enclosure & & & \\
R-13 insulation & $\left(\mathrm{m}^{3}\right)$ & 258 & 115 \\
Steel stud framing & $\left(\mathrm{m}^{2}\right.$ @ 406 mm O/C $)$ & 1,617 & - \\
Wood stud framing & $\left(\mathrm{m}^{2} @ 406 \mathrm{~mm}\right.$ O/C $)$ & - & 1,617 \\
Gypsum wall board & $\left(\mathrm{m}^{2}\right.$ of 13 mm thickness $)$ & 1,929 & 1,929 \\
\hline
\end{tabular}

\subsection{Life Cycle Impact Analysis: Building Design Comparison}

Figure 2 shows the comparative life cycle environmental performance of the concrete and timber design alternatives of Discovery Place-Building 12. The life cycle impact assessment comparison illustrated that the laminated timber design scenario had a lower environmental impact than the cast-in-place reinforced concrete building in 10 of 11 impact categories. In all impact categories, the laminated timber and concrete data were normalized with respect to one another. At a minimum, the heavy timber-framed building demonstrated a 14\% improvement over its concrete-framed counterpart, while at a maximum; the timber building was estimated to have a contribution to global warming potential that was $71 \%$ lower than the concrete design. Fossil fuel depletion was the only impact category where the concrete-framed design was superior, displaying a $6 \%$ improvement over the laminated timber scenario. The impact categories, along with the methodology, model definitions, and explanations of the cause-effect chain of each impact category (mid-point $v$ s. end-point effects), 
including the level of site specificity were developed by the USEPA for the TRACI program and are discussed in Bare et al. [11] and Lippiatt [12].

Figure 2. Environmental impact comparison of the concrete and timber design alternatives.

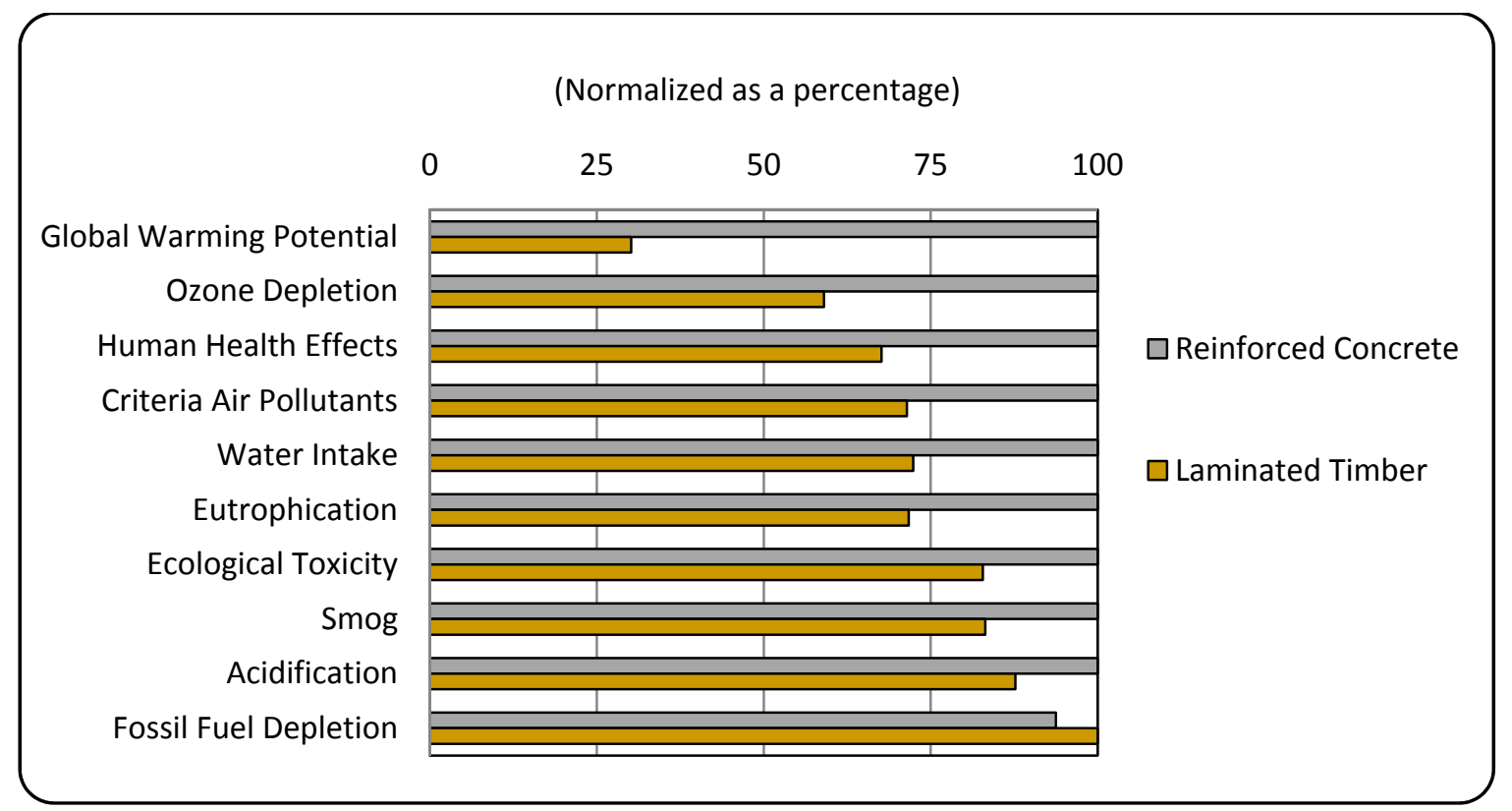

\subsection{Embodied Energy}

The total embodied energy for each alternative design scenario was also calculated and categorized for comparative information and discussion; with the heavy timber and reinforced concrete building designs having cumulative embodied energy contents of 117 and 66 terajoules or 8.2 and $4.6 \mathrm{GJ} / \mathrm{m}^{2}$, respectively. Embodied energy (EE) was defined as the cumulative amount of primary energy consumed and stored throughout the raw materials acquisition, product manufacturing and transportation stages (i.e., from cradle-to-gate). The EE was accounted for and classified in two ways; by fuel renewability (Figure 3a) and by process and feedstock energies (Figure 3b). Fuel renewability was separated into energy derived from non-renewable (petroleum, natural gas, coal, and other fossil fuels) and renewable (hydro, wind, biomass, geothermal, and nuclear) sources. Process energy accounts for the amount of energy that was released when fuels are utilized or combusted during the production or operation of an industrial process (i.e., burning fossil fuels to operate a truck). Feedstock energy is the potential energy contained in fuel resources that are extracted from the Earth; such as the potential energy contained in bio-based wood products or fossil fuel based adhesives and insulation contained within the building's structure and envelope. 
Figure 3. (a) Embodied energy of building materials by fuel renewability; (b) Embodied energy of building materials (feedstock and process energy).

(a)

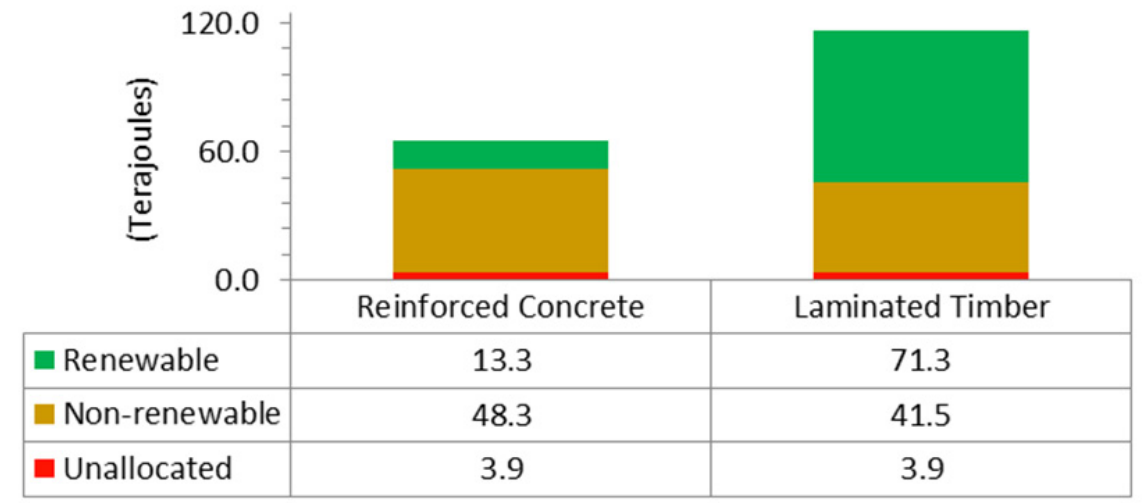

(b)

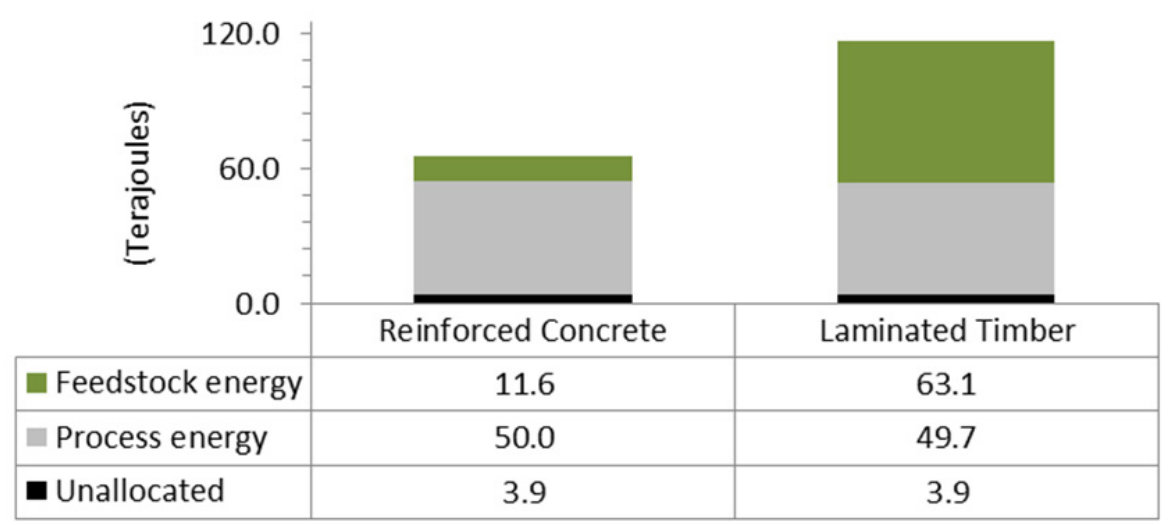

\subsection{Uncertainty Analysis}

Uncertainty appears in almost all stages of an LCA study and can be described as "the discrepancy between a measured or calculated quantity and the true value of that quantity" [13]. The reliability of the LCA results was an important consideration in the comparative LCA of Discovery Place-Building 12. All phases of the study, in particular, life cycle inventory (LCI) data collection and life cycle impact assessment (LCIA) modelling, were undertaken with a high degree of precision and quality control. Despite the level of care taken in conducting the comparative LCA, a degree of uncertainty was, inevitably, still present in the results. This uncertainty was derived from several sources including data quality, environmental modeling techniques, and system boundary selection to name a few.

In order to accurately quantify uncertainty in numerical terms, it was necessary to be provided with relatively large data sets in which statistical distributions could thereby have been calculated and analyzed. The LCI data sets that were used for building materials did not come with attached statistical distributions and therefore, it was not possible to calculate the uncertainty associated with the LCIA results in numerical terms. All secondary data, primarily from BEES ${ }^{\circledR} 4.0$, ASMI, and the US LCI did not contain any information on the associated probabilistic distributions of the data sets. The primary data for the production of CLT was collected from only one pilot plant facility, thereby making it impossible to determine variability across several manufacturing facilities.

This study does not include a numerical uncertainty analysis, as there were no statistical distributions connected with either the primary or secondary LCI data. This made it impossible to 
calculate distributions associated with LCI data, along with the accompanying confidence intervals and standard deviations in the LCIA results. It is important to keep this in mind when using LCA as a comparative decision making tool. The results generated in this study are based on relevant resource extraction, production, and transportation data sources, in tandem with scientifically grounded assumptions and estimates. The consequence of the final LCIA results was determined by the quality of the LCI data; input conditions will inevitably be reflected in the output results. LCA results are often viewed through a blurry lens; they are accurate enough to be used for decision making purposes, but due to the ever changing nature of technology, manufacturing processes, and environmental modelling techniques, LCA results can often have shifting means, medians, and absolute values. This is often the case with many past and present LCA studies and must be acknowledged when using LCA as a tool in the decision making process.

It was possible to have assumed and fitted probability distributions to the LCI data and then used these assumptions to calculate the inherent numerical uncertainty of the LCIA results using Monte Carlo methods. This approach was not taken as it was considered to be an exercise that would have clouded and overcomplicated the final results, while providing little additional guidance for decision makers. Instead, the study undertakes several sensitivity analyses, both quantitative and qualitative in nature, that aim to confirm the validity and conservativeness of key assumptions. The subsequent sensitivity analyses also attempted to shed light on the inclusion of alternative life cycle stages and boundary condition scenarios, in an attempt to exhibit the robustness of the study's results.

The LCA study conducted was compiled using a process-based approach. That is, when calculating the environmental effects of building materials, only the direct, or zeroeth-order inputs and associated outputs are considered. For example, when determining the environmental impacts associated with a tonne of steel, the burdens related to the manufacture of the mill's machinery were not considered; when calculating transportation effects, only the fuel used was included in the LCA profile, not the indirect or secondary impacts associated with the manufacture of the vehicle. In order to fully account for all embodied environmental effects of a building material, it is necessary to perform an economic input-output (EIO) analysis of the entire economy. Harvey [14] states that "to rely entirely on a process based approach will underestimate the true embodied energy and subsequent environmental burdens, since interactions beyond some relatively low order will be omitted (that is, there is a truncation error)". The LCI data that was obtained from sources such as the US LCI, ASMI, and BEES ${ }^{\circledR} 4.0$ was developed using a process-based analysis; although the truncation or cut-off criteria was not provided and possibly varied between data sets. Due to the nature of the process-based LCA calculation methodology, the absolute values of the LCIA results for both the concrete and timber building cases are expected to be lower than if an EIO based methodology was used. A comparative Australian study of a concrete- and wood-framed building demonstrated that indeed the process-based LCA methodology underestimated the absolute value of the energy requirements and GHG emissions by a factor of two, when compared to an EIO approach, but the final results of the comparative study remained the same regardless of the methodological approach; that is, the concrete-framed building caused higher emissions [15]. It would be expected that the cradle-to-gate environmental impacts of Discovery Place-Building 12 would increase in absolute value if an EIO approach was used but the comparative results of the study would not be expected to change. 


\subsection{Sensitivity Analysis}

Sensitivity analyses were performed in an attempt to test the reliability and robustness of the study's results and assumptions. The first sensitivity analysis increased the percentage of fly ash in the concrete mix from $15 \%$ to $20 \%$ in both the concrete- and heavy timber-framed building design scenarios. An addition of $10 \%$ to the material quantities of both CLT and glulam in the heavy timber design scenario was applied as a second sensitivity analysis.

\subsubsection{Lower Impact Concrete Mix: A 5\% Increase in Fly Ash Content}

Supplementary cementing materials ( $\mathrm{SCMs}$ ) are waste products that are used as substitutes for portland cement when making concrete. Common SCMs include blast furnace slag and fly ash, which are waste products from steel production and coal-fired power plants, respectively. Silica fume and limestone are also used as SCMs. This sensitivity analysis will focus on the use of fly ash; a waste material that is left over when coal is burned to generate electricity. "In LCA terms, fly ash is an environmental outflow of coal combustion, and an environmental inflow of concrete production. This waste product is assumed to be an environmentally "free" input material. The environmental burdens associated with the production of waste materials are typically allocated to the intended product(s) of the process from which the waste results." [16]. Therefore, when fly ash was considered in the LCA of Discovery Place-Building 12, the only direct environmental burdens associated with it were derived from the transportation of the product from the coal-fired generating station to the concrete ready mix plant.

The original LCA input data for concrete production assumed a $15 \%$ fly ash content in the cement mix for both the concrete and laminated timber design scenarios. The sensitivity analysis increased the percentage of fly ash in the mix from $15 \%$ to $20 \%$ in both the concrete- and heavy timber-framed building design scenarios.

The sensitivity analysis related to increasing the fly ash content to $20 \%$ in the concrete mixes for both the reinforced concrete- and laminated timber-framed buildings yielded results that were almost identical to the original LCA impacts, which used a 15\% fly ash concrete mix. Only four impact categories recorded an improvement of $1 \%-2 \%$ with respect to the concrete-framed design over the heavy timber design; these being global warming, smog formation, eutrophication, and fossil fuel depletion potentials, whereas all other environmental impact categories remained unchanged. With respect to total embodied energy, both the concrete and timber designs saw a reduction of approximately $1 \%$ in the cumulative embodied energy of construction materials.

These sensitivity results demonstrated that a simple alteration of the concrete mix, by adding $5 \%$ more fly ash, led to a $1 \%-2 \%$ relative improvement of the reinforced concrete design over the timber design in four of eleven environmental impact categories. It was anticipated that adding more fly ash would have had a much greater impact on improving the environmental and embodied energy performance of the concrete-framed building over the timber-frame due to the fact that the concrete building contained a much higher volume of reinforced concrete structure than the heavy timber design. Nonetheless, this result indicated that the effect of using a concrete mix containing higher fly ash content did not significantly reduce the environmental impacts of the concrete-framed building 
relative to the heavy timber design. The $20 \%$ fly ash content aided in marginally decreasing the environmental and energy impacts of both building design scenarios, but was not a major catalyst in reducing the environmental effects of the reinforced concrete design over the laminated timber design.

\subsubsection{Laminated Timber Material Quantities: An Increase of $10 \%$}

The heavy timber redesign of Discovery Place-Building 12 was based on material design properties for CLT that were developed through mechanical testing of sample specimens [17,18]. The design properties that were calculated are based on bending tests from a small sample size of CLT panels that were considerably smaller in length, width, and depth than typical CLT elements that would have been specified in the construction of a mid-rise, five-storey office building such as Discovery Place-Building 12. In addition to the CLT design criteria considerations, the structural design process of the timber building consisted of determining worst case loading scenarios for the CLT floor plates and walls, as well as the glulam beams and columns. These worst case scenarios were then used to design structural members that were subsequently used for all other, less stringent loading situations. With enhanced mechanical testing regimes and greater sample sizes related to the material performance characteristics of both the horizontal and vertical CLT elements, more accurate structural design properties could be established. It is not yet known how alternate material testing, sample size variation, and the resulting changes in design values would affect the material quantity of CLT in the timber building design scenario. In order to consider one variation of the laminated timber material quantity outcome, a variance of $+10 \%$, when compared to the bill of materials listed in Table 3, was applied to the material quantities of both CLT and glulam in the heavy timber design scenario. The outcomes of the sensitivity analysis that increased the laminated timber quantities by $10 \%$ are shown as Figure 4.

Figure 4. Comparative LCA results for a 10\% increase in laminated timber volumes.

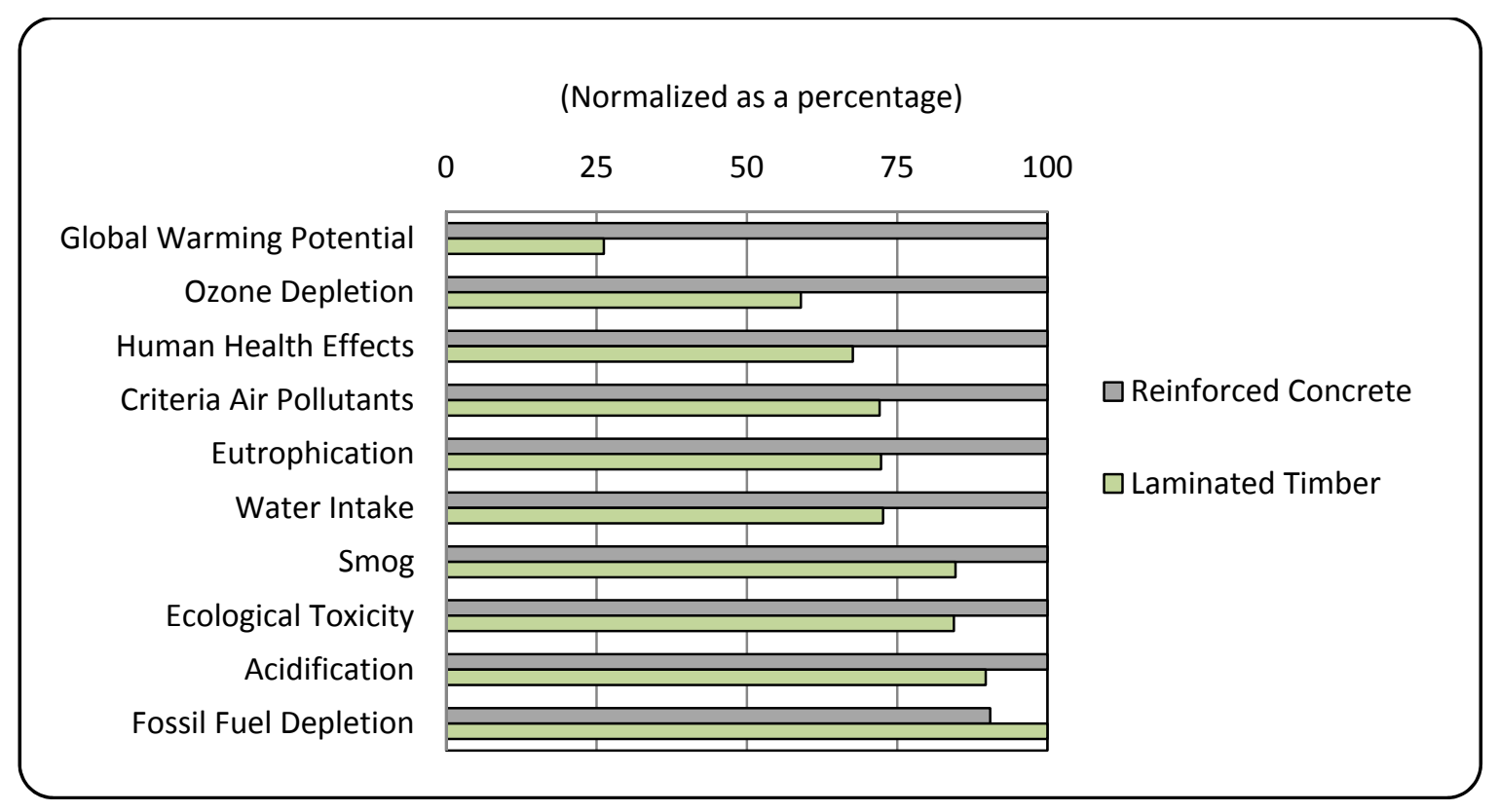

Increasing the volume of laminated timber (CLT and glulam) in the heavy timber design scenario yielded results that were relatively inconsequential, given the level of underlying uncertainty. With the 
addition of $10 \%$ more laminated timber in the wood-framed design, the environmental performance of the timber building decreased from a minimum of less than $1 \%$ up to a maximum of $4 \%$, relative to the reinforced concrete design. The most prevalent effect was recorded in the fossil fuel depletion impact category, which measured a $4 \%$ decline in the relative environmental performance of the laminated timber design, with most other categories showing a 1 or $2 \%$ variation. An interesting result that was also observed in this sensitivity analysis was the fact that the global warming potential of the timber building actually improved by $4 \%$ over the concrete-framed design, even with the addition of $10 \%$ more laminated timber to the building structure. This improvement was a result of the fact that when considering the carbon storage properties of wood, both glulam and CLT store more $\mathrm{CO}_{2}$ equivalent than they release during their cradle-to-gate life cycles. With respect to total embodied energy, the addition of $10 \%$ more laminated timber resulted in an increase of just over $6 \%$ or 7 terajoules of energy when compared to the cumulative embodied energy content of the original timber design scenario.

\section{Discussion}

\subsection{LCA of Wood Products}

\subsubsection{Adhesives}

The use of different types of structural adhesives; phenol resorcinol formaldehyde (PRF) versus polyurethane (PU), which are employed to face bond the adjacent ply layers of CLT panels and the lamellas of glulam members, was considered at the outset of the study. LCI data sets representing North American and European-made PRF glue were available, as this product had been used extensively on both continents for the past three decades. PU, on the other hand, is relatively new to both the European and North American markets and at present, there exists no publically available LCI data for this product, therefore it was impossible to compare EWPs made with either PRF or PU on an environmental basis. The fossil fuel feedstock and the intensive manufacturing processes that are required for the production of both PRF [19] and PU adhesives, in conjunction with the fact that a cold setting PRF adhesive was modelled in the study, led to the conclusion that the application of PRF adhesive was both suitable and conservative in the North American context. Despite the fact that both PRF and PU have considerable environmental effects when considered alone on a per kilogram basis, only a low volume of either PRF or PU adhesive is required to produce a large volume of laminated timber. For this reason, the substitution of PU for PRF in the CLT and glulam structural applications is not anticipated to change the overall study results significantly.

\subsubsection{Carbon Accounting}

When considering the carbon analysis wood products, it is important to outline the inclusions and exclusions that were taken into account when determining the net carbon consequence and GWP of biomass based building products. There are several defined ways in which wood products have the ability to contribute to climate change mitigation, as outlined by Werner et al. [20]: 
"They act as a carbon pool during their service lives, as they withdraw $\mathrm{CO}_{2}$ from its natural cycle furthermore, wood products can substitute for more energy-intense products after their service life, they can substitute for fossil fuels if they are incinerated."

This study follows the carbon accounting guidelines set out by the IPCC [21], which consider any GHG emissions generated by the combustion of biomass based material to be carbon neutral. Therefore, any environmental impact generated from a biomass source, such as hog fuel or wood residues combusted in a sawmill, will not appear in the GWP impact category. The accounting legitimacy and scientific basis for considering the combustion emissions from biomass products as climate impact neutral is currently under debate [22], but will not be discussed further, as it is outside the scope of this study. The environmental burdens associated with bioenergy generation were measured in all other environmental impact categories and were accounted for as renewable embodied energy. The potential energy contained within the building's structure and envelope, such as wood framing, EWPs, and other bio-based building products, are considered feedstock energy sources in the embodied energy accounting method. The carbon stored in EWPs was accounted for as a negative value in the GWP category. Carbon storage of wood varies by species and density but is generally considered to be $1.84 \mathrm{~kg}$ of $\mathrm{CO}_{2}$ equivalent per $\mathrm{kg}$ of harvested, oven-dry wood [12]. In order to be relatively precise and conservative in the estimate of carbon stored in the wood products contained within the two design scenarios of Discovery Place-Building 12, the density of CLT, glulam, and framing lumber was taken as $409 \mathrm{~kg} / \mathrm{m}^{3}$.

The total volume of wood contained in the heavy timber design scenario was approximately $4,161 \mathrm{~m}^{3}$, which stored roughly 3,131 tonnes of carbon dioxide equivalent within the building structure and envelope makeup. If the carbon storage property of wood was not included in the GWP calculation, the total amount of $\mathrm{CO}_{2}$ equivalent associated with the cradle-to-gate emissions analysis would have been 4,930 tonnes, still over a kilotonne less than the reinforced concrete alternative. When considering GHG emissions, the heavy timber design alternative outperformed the concrete-framed counterpart by over $70 \%$ when taking into account carbon storage and by $17 \%$, even when the carbon storage property of wood was not considered.

The carbon savings that was possible by substituting biomass based energy sources for fossil fuel based sources during the production of building materials, was not calculated or reflected in the environmental impacts or the numerical energy accounting results. There was no GHG displacement factor applied or any credit given, with respect to either environmental impact or embodied energy, for the use of timber products over other more energy intensive substitutes (e.g., wood studs vs. steel studs). It was viewed as conservative to refrain from utilizing displacement factors when accounting for the substitution of building materials or renewable for non-renewable energy sources. Due to the lack of availability, combined with the variability of displacement factor magnitudes, it was viewed as an unsuitable environmental impact quantification metric, that risked increasing the underlying complexity of the study without offering any added precision. 


\subsection{EE and GWP: Analysis and Literature Comparison}

Table 4 illustrates the embodied energy (EE) and global warming potential (GWP) results for Discovery Place-Building 12, as compared to other North American-specific LCA studies that were performed on commercial building structures over the past two decades.

Table 4. Comparison of study results to existing whole building LCA literature.

\begin{tabular}{lll}
\hline Study authors & Embodied energy $\left(\mathrm{GJ} / \mathrm{m}^{2}\right)$ & GWP $\left(\mathrm{kg} \mathrm{CO} \mathrm{CO}_{2} \mathrm{eq} . \mathrm{m}^{2}\right)$ \\
\hline Reinforced concrete frame & & - \\
Cole, R.J. [23] & 4.93 & - \\
Hood, I.W. [24] & 4.26 & - \\
Cole, R.J.; Kernan, P.C. [25] & 4.79 & - \\
Kernan, P.C. [26] & 4.03 & 287 \\
CWC [27] & 1.38 & 550 \\
Guggemos, A.A.; Horvath, A. [28] & 8.30 & 844 \\
Krogmann et al. [29,30] & 17.9 & 420 \\
Robertson et al.-This Study & $4.60^{\mathrm{F} \& \mathrm{P} / 3.51^{\mathrm{P}}}$ & \\
Timber frame & & 40.7 \\
Marcea, R.L.; Lau, K.K. [31] & 0.74 & - \\
Cole, R.J.; Kernan, P.C. [25] & 4.54 & 159 \\
CWC [27] & 0.81 & $89.0^{*}$ \\
Gustavsson et al. [32] & 3.51 & $126^{*}$ \\
Robertson et al.-This Study & $8.17^{\mathrm{F \& P} / 3.49^{\mathrm{P}}}$ & \\
\hline
\end{tabular}

* Carbon storage of wood is considered as a credit (i.e., negative); F\&P $=$ Feedstock \& process energy included; $\mathrm{P}=$ Process energy only.

As the above results dictate, it is often difficult to compare one LCA study to another. Although all the studies listed in Table 4 were whole-building LCA studies, similar in scale and scope, each one used a different size and height case study building, altered or expanded LCI building material input data, as well as utilizing either a process-based LCA, an EIO model, or a combination of both. These variations, in addition to differences in energy accounting (inclusion or exclusion of feedstock energy) and environmental modeling rationale, will cause skewing across studies and lead to a degree of incomparability between LCA study results. The first result that can be demonstrated from Table 4 is that the LCA results for Discovery Place-Building 12 were similar, within the same order of magnitude with respect to embodied energy and GWP, to all other relevant LCA studies. Throughout all the studies, it is clear that there is an overarching trend demonstrating that timber-framed buildings generally have a lower GWP than concrete and steel structures. A trend relating embodied energy (EE) and structural configuration was less discernible, especially when you attempt to analyze the results from this study, whereby the cumulative EE of the laminated timber building exceeded that of the reinforced concrete design.

When considering both feedstock and process energy, the EE associated with the heavy timber-framed design of Discovery Place-Building 12 exceeded the EE of the reinforced concrete scenario by a factor of 1.78 or almost $80 \%$. At the outset of this research project, this result was not anticipated, as many past LCA studies have demonstrated wood-framed structures to have lower EE than concrete or steel 
alternatives, as shown in Table 4. It is important to note that none of the contemporary LCA studies considered the use of laminated timber (glulam and CLT) in a five-storey, non-residential application. Most other comparative LCA studies, such as [25] and [31] have employed light wood-frame construction techniques when designing a mid-rise timber building (although [27] used a combination of exterior stud walls, wood I-joists, and glulam members). The difference in EE between the concrete and timber cases of Discovery Place can be directly tracked to the volume and corresponding EE content of the laminated EWPs used in the heavy timber design scenario. The total volume of laminated timber (glulam and CLT) used in the redesign of Discovery Place-Building 12 was $4,147 \mathrm{~m}^{3}$, accounting for $88 \%$ of the feedstock energy, but only $33 \%$ of the process energy in the timber design scenario. Comparatively, the amount of concrete that was required in the above-grade portion of the reinforced concrete building design was $4,243 \mathrm{~m}^{3}$ (Table 3); demonstrating that less wood material was used in the timber redesign of the superstructure than in the original concrete-framed case.

It was expected that less material volume would be required in the superstructure of the timber design case, as the building weight was greatly reduced by using wood instead of reinforced concrete, but it was not expected that less material would result in greater EE. Although laminated timber appears to contain more EE than an equivalent volume of reinforced concrete, the origins and accounting principles associated with the EE calculation need to be well understood.

When calculating the EE of laminated timber products, it is important to differentiate between process and feedstock energy. Process energy accounts for the amount of energy that was released when fuels are utilized or combusted during the production or operation of an industrial process (i.e., burning fossil fuels to operate a factory). Feedstock energy is the easily accessible potential energy contained in fuel resources that are extracted from the Earth; such as the potential energy contained in bio-based EWPs or the natural gas feedstock contained within the molecular structure of the fossil fuel based wood adhesives. Comparing the feedstock energy of the concrete and timber-framed designs, we can see that the timber design has over five times more feedstock energy than the concrete design scenario (Figure 3b). This is due to the fact that the timber elements within the building store potential energy contained within the wood fibre and within the fossil fuel-derived adhesive resins. The high amount of feedstock energy is an indicator that both the CLT and glulam products can be readily combusted and utilized as energy sources after their useful lives. In the case of reinforced concrete, incineration is not practical or commonplace, making it difficult to easily obtain useful energy at the end of its service life. This is not to say that the reinforced concrete does not store potential energy; it does, as all matter stores energy, but it does not store readily accessible energy that can be easily extracted at the end of its service life. There was very little energy allocated to the feedstock category of concrete because it does not contain, within the final product, fuel inputs that come directly from the Earth (such as fossil or bio-based fuels). Almost all the energy used to produce concrete appears in the process energy category. Fuel inputs from the Earth are used in the production of concrete (i.e., natural gas to heat the cement kiln) but are not present within the final material product. In the case of this LCA study, the higher content of feedstock energy in the heavy timber design alternative is not indicative of an environmentally inferior material selection, but instead demonstrates that there is a larger amount of easily accessible potential energy contained in the timber design than the concrete design. 
With respect to process energy, there was relatively no difference between the concrete- and timber-framed alternatives (Figure 3b); meaning that approximately the same amount of energy was released throughout the production and operation of the industrial processes associated with the manufacture of the building materials in both design scenarios. This result was unexpected and can be justified through two primary explanations. First, almost all previous studies have compared cast-in-place concrete construction to light-frame wood construction. The fundamental difference between light-frame (i.e., platform- or stick-frame) and heavy timber (glulam and CLT) construction is the volume of wood required. Heavy timber construction requires much larger volumes of wood, which in turn, results in higher process energy demands. Second, a large portion of the process energy in the timber design scenario was attributed to the production of CLT. Due to the fact that the primary energy accounting data for the production of CLT was derived from a small-scale pilot facility, it is conceivable that the process energy per functional unit of CLT could be reduced, if process energy data was collected from a full-scale CLT manufacturing facility. Plausibly, this could result in the laminated timber design scenario having a lower process energy demand than the cast-in-place concrete design.

It is interesting to combine the finding of identical process energy requirements (Figure $3 \mathrm{~b}$ ) for both design scenarios with the energy accounting of fuels based on their renewability (Figure $3 a$ ). The concrete building attained $20 \%$ of its EE from renewable sources, whereas in the case of the heavy timber-framed building, renewables accounted for over $60 \%$ of the total EE. With respect to the absolute value of non-renewable EE, the amount associated with the concrete design case was greater than the timber case by almost 7 terajoules. Knowing this, when we now look at the fact that the concrete and timber-framed buildings use the same amount of process energy $\left(\sim 3.5 \mathrm{GJ} / \mathrm{m}^{2}\right)$, it is reasonable to ascertain that a much higher percentage of this process energy was derived from renewables, in the case of the timber building, when compared to the reinforced concrete design. It is possible and would have been advantageous to determine the numerical value of fuel renewability associated with process energy (i.e., how much of the process energy was associated with renewable sources; such as the combustion of biofuels for heat energy), unfortunately a detailed comparison of this sort was not possible, as all of the building material LCI data sets were not aggregated in such a manner. The comparative data regarding fuel renewability indicated that despite the timber-framed building having more associated cumulative EE, much more of this energy was derived from renewable sources. In addition, the absolute value of non-renewables was calculated to be $14 \%$ less than the concrete building design case. Recalling that the timber building design demonstrated superior environmental performance in all but one impact category, yet demonstrated a much higher cradle-to-gate embodied energy total (feedstock plus process), it became apparent that in the case of this particular LCA study, it was not accurate to directly correlate embodied energy results with environmental impacts.

\subsection{Inclusion of On-Site Construction/Erection Stage}

A literature review of contemporary research findings that related to the environmental impacts associated with the construction phase of North American, mid-rise office buildings was performed in order to apply previous findings to the design context of Discovery Place-Building 12. The goal of the following discussion and sensitivity analysis was to look beyond the cradle-to-gate study boundaries 
and approximate the relative environmental and energy use differences that existed in the construction stage of the concrete- and heavy timber-framed design alternatives of a five-storey office building. The aim was also to determine how the expansion of the cradle-to-gate system boundary (Table 1), to include the on-site construction phase, would affect the comparative LCA results profile of the concrete and heavy timber design alternatives.

According to the Canadian-based study by Cole R.J. [33], there are five general categories that influence the environmental impacts and energy use of on-site construction:

1. The transportation of the building crew to and from the construction site for the duration of their construction task;

2. The transportation of materials from a distribution centre to the construction site;

3. The transportation of equipment specific to the construction task to and from a central depot to the building site;

4. The use of on-site equipment specific to the construction task;

5. Supporting processes such as form-work and temporary heating.

When considering all of the above influence factors relating to on-site construction impacts only, [33] found that with respect to construction energy use and related GHG emissions impacts per square metre of floor area, glulam structural frames (spans of 6.1-9.2 m), overlaid with $50 \mathrm{~mm}$ tongue and groove decking, fell between $17-20 \mathrm{MJ} / \mathrm{m}^{2}$ and $2.3-2.5 \mathrm{~kg} \mathrm{CO}_{2}$ eq. $/ \mathrm{m}^{2}$, whereas cast-in-place reinforced concrete walls (200-300 mm thick), flat plate slabs and columns (spans of 6.1-9.2 m) required the highest construction energy at $90-120 \mathrm{MJ} / \mathrm{m}^{2}$ and were responsible for the largest GHG emissions at $13-20 \mathrm{~kg} \mathrm{CO}_{2}$ eq. $/ \mathrm{m}^{2}$ recorded in the study. Cole, R.J. [33] also remarked that "cast-in-place systems are among the highest within the group of concrete structural systems that also included concrete block, precast and tilt-up construction and entail greater energy in transporting workers to and from the building site (approximately $40 \%-50 \%$ of the total)". Additional interesting findings that related to the LCA comparison of Discovery Place-Building 12 that were drawn from the study [33] included; (a) "for glulam beams...energy use per $\mathrm{m}^{2}$ decreases with increased load and decreases slightly to moderately with increased span"; and (b) "those systems requiring heavy on-site equipment (e.g., cranes) tend to show savings in energy use per square metre as size or load increases since the same energy is expended within the equipment's capacity, regardless of material size". Quantitatively, this LCA study found that for glulam-framed assemblies, the construction energy, as a percentage of total embodied energy, ranged from $6 \%-14 \%$ and GHG emissions as a percentage of initial embodied GHGs, ranged from $8 \%-14 \%$, whereas with cast-in-place concrete, the ranges for energy and GHG emissions were considerably higher at $13 \%-25 \%$ and $15 \%-25 \%$, respectively. Steel-framed assemblies demonstrated the overall lowest on-site construction energy and GHG emissions levels in the study [33], being marginally lower than those of wood-framed construction systems, whereas concrete systems were generally an order of magnitude larger than both steel- and wood-framed structures, with respect to both construction energy and associated GHG emissions. In almost all construction assemblies, this study found that transportation of workers to and from the job site represented the largest portion of energy use during the on-site construction process.

Junnila et al. [34] also found that when the transportation of workers to and from the job site was not considered, "equipment use accounts for the majority of energy use and emissions in the construction 
stage" of a five-storey, concrete-framed office building in the U.S. With respect to the entire building life cycle (materials, construction, and end-of-life phases), Guggemos A.A. and Horvath A. [28] found that "construction phase impacts represent a relatively small part $(0.4 \%-11 \%)$ of the overall building life cycle energy use and emissions". In order to minimize the on-site construction phase impacts of a mid-rise office buildings, [28] specified the areas which would generate the largest environmental and energy savings, including; "minimizing the amount of temporary materials used, including reusing temporary materials if possible more prefabrication work and the use of standard sizes in design can also help". In a later publication, Guggemos, A.A. and Horvath, A. [35] also remarked that "prefabrication should be favoured over on-site fabrication due to higher productivity, reduced equipment use, and reduced waste generation". Although not measured directly in their LCA study, [28] noted that "waste generation at the construction site is also of concern, particularly excess concrete materials".

Taking into consideration the above research findings directly related to the construction of mid-rise building systems, it was possible to extrapolate these to the comparative designs of the Discovery Place-Building 12 office structure. The first stark difference between the construction sequences of a five-storey concrete or heavy timber (glulam and CLT) structural system was the variation in the erection times. A reinforced concrete-frame required significantly more on-site time and manpower in order to build formwork/falsework, place rebar, pour concrete, allow time for curing, and finally strip the forms. This was not the case with the heavy timber building design, as all glulam beams and columns, as well as CLT walls and floor plates are prefabricated off-site and arrive at the construction site cut to size, often with service openings pre-drilled and can be erected almost immediately after being lifted off the truck bed. As an example, according to [36], the Stadthaus, a nine-storey CLT apartment building in London, England was erected in 49 weeks with a mobile crane and no use of temporary scaffolding for the structure; taking a four man crew only 27 working days to erect the eight-storeys of CLT superstructure. It was estimated that an equivalent concrete structure would have taken 72 weeks to erect and required the use of a tower crane, temporary formwork and scaffolding. A second British example of CLT construction, Kingsdale School, expressed that "the use of cross-laminated timber panels offered many other advantages including improved on-site erection periods, sustainability, omission of wet trades and factory quality finishes" [37]. In addition to the rapid erection time, timber buildings require only simple power tools for drilling and coring when compared to the heavy equipment required for concrete or steel construction alternatives. The use of smaller construction equipment may well lead to a reduction in on-site electricity use, noise, and dust generation.

The Canadian study, [33], clearly demonstrated the lower energy use and GHG emissions associated with the construction of glulam-framed buildings over cast-in-place reinforced concrete structures. As well, extrapolating from these results, glulam-framed buildings may have increased performance when considered in the larger, mid-rise building context, as energy use per square metre tended to decrease with increased load and span. Further energy and environmental savings could be realized in the timber design scenario through the use of smaller construction specific tools and equipment, the absence of temporary materials such as formwork and scaffolding, and a shortened construction schedule, leading to less energy and emissions expended for workers travelling to and from the job site. Additionally, according to [35], the notion of prefabrication in heavy timber 
construction, as it relates to glulam and CLT designs, provides an opportunity for higher construction efficiency and productivity, along with reduced equipment use and on-site waste generation.

Based on the literature review and the analysis of the construction schedule, manpower, equipment, and temporary materials requirements, it can be estimated that the construction of the heavy timber design alternative will most likely generate lower GHG emissions and use less energy during construction than its cast-in-place reinforced concrete counterpart. This conclusion results from the decreased on-site construction time, the availability of pre-fabricated structural elements, and the reduction in temporary construction systems (i.e., formwork and falsework) required for the construction of the laminated timber-framed building. The quantitative value of exactly how much less of an effect the timber-framed design will have during the construction phase remains unclear, although results based on the work by Cole R.J. [33] estimated that an improvement of four-fold with respect to GHG emission per square metre and eight-fold with respect to energy use per square metre may be plausible, although the effects of construction/erection when considered as part of the full building life cycle may be relatively minor. It was not possible to gauge the relative changes that may occur in any other environmental impact categories, as previous studies had only focused on energy use and GHG emissions.

\subsection{End-of-Life: Demolition and Disposal}

Buildings will inevitably reach the end of their functional life cycle; whether the justifications for retirement are "changing land values, lack of suitability of the building for the current needs, lack of maintenance of various non-structural components" [38] or structural failure beyond repair; end-of-life scenarios must be duly considered and addressed when taking into account a full life cycle agenda.

The research related to the environmental effects and energy use associated with the demolition phase of a North American, mid-rise office building shows a consistent trend with respect to energy use, despite the numerical values being variable. The studies that compared wood and concrete building systems $[39,40]$ found that wood-framed buildings consistently demonstrated the lowest demolition energy per unit area. There was evidence that suggested the demolition energy use and GHG emissions were between 3\%-8\% of the total embodied energy and emissions for concrete-framed buildings [29,34] whereas these values were only $1 \%$ for a heavy timber-framed building [32]; over a 50 -year life cycle, when not accounting for biomass recovery and operational energy use. This evidence suggests that mid-rise, wood-framed office structures use less energy during the demolition phase, in conjunction with the demolition phase having a slightly lower relative impact on the overall life cycle energy use and GHG emissions profile. The concrete-framed design may have an advantage if demolition were to take place under inclement or winter weather conditions, as the use of heavy machinery is less affected by weather than manual labour. Considering overall impacts, if the demolition phase were to be included in the comparative LCA framework of Discovery Place-Building 12, the heavy timber design alternative may likely outperform the cast-in-place reinforced concrete design, when considering only energy use and GHG emissions. It was impossible to estimate any other relative environmental impacts, as there was no applicable data that documented other impact indicators $\left(\mathrm{SO}_{2}, \mathrm{NO}_{\mathrm{x}}, \mathrm{PM}_{10}\right.$, etc.) related to the demolition of wood-framed buildings. 
In addition to energy use and GHG emissions associated with the demolition phase of a building's life cycle, it is also prudent to discuss the disposal options that exist for both reinforced concrete- and heavy timber-framed structures. After the demolition phase, building materials can be recycled or reprocessed, reused, disposed of in a landfill or converted to useable energy. ASMI [40] found that demolition time periods and energy requirements were generally higher when structural building materials were envisioned to be reused after the demolition process, as opposed to recycled. In reference to Discovery Place, the reuse option seems more feasible with the heavy timber building design; structural members could essentially be disassembled, as both glulam and CLT components were originally designed and shipped as individual, prefabricated elements. Reuse, in the original form, may be more difficult with a cast-in-place reinforced concrete structure, due to its systemic design and monolithic construction. Recycling or reprocessing could be applied to both the timber and concrete systems, as EWPs and dimensional lumber could be chipped and reprocessed as other, lower grade wood products, such as particle board or oriented strand board. Similarly, reinforced concrete can be crushed and used in low-specification applications such as backfill or bedding material for road construction. Crushed concrete can also substitute for natural aggregates in the production of new concrete [41], although it is generally blended with fresh aggregate [42]. The steel rebar can be recycled in order to make other useful, lower-grade metal products. The option of energy recovery was available only for the heavy timber structure in the form of heat or electricity generation. There are several locations along the wood products value chain that generate biomass waste products (including building demolition), which are capable of being used as biofuel to generate energy. The accessibility of potential energy in the heavy timber-framed design was reflected in the feedstock category of the building's embodied energy calculation (Figure 3b). Finally, disposal of building products in a landfill was an option for both the concrete- and timber-framed alternatives of Discovery Place.

It was difficult to estimate with certainty whether the concrete- or timber-framed design was more environmentally advantageous with respect to end-of-life disposal options. It was evident that the timber-framed design alternative of Discovery Place-Building 12 had additional disposal options, including reuse and biomass energy recovery, which were not as relevant or applicable to the reinforced concrete design scenario.

\section{Conclusions}

As building operational energy use and associated emissions are reduced through efficiency measures and renewable energy generation, the importance of embodied energy and environmental impacts associated with other life cycle stages becomes more significant.

This study performed a comparative LCA between a reinforced concrete- and laminated timber-framed mid-rise office building, located on the West Coast of Canada. The results indicate that when considering a mid-rise office building, it is environmentally advantageous, in all but one impact category, to construct the structural frame and the enclosure system using predominantly laminated timber engineered wood products, rather than cast-in-place reinforced concrete construction. When considering both feedstock and process energy, the embodied energy associated with the heavy timber-framed design of Discovery Place-Building 12 exceeded that of the reinforced concrete scenario by almost $80 \%$. At the outset of this research project, this result was not anticipated, as many 
past LCA studies have demonstrated wood-framed structures to have lower EE than concrete alternatives. It is important to note that none of the contemporary LCA studies considered the use of laminated timber (glulam and CLT) in a five-storey, non-residential application. Most other comparative LCA studies examined light wood-frame construction techniques when designing a mid-rise timber building. In the case of this LCA study, the higher content of feedstock energy in the heavy timber design alternative is not indicative of an environmentally inferior material selection but instead demonstrates that there is a larger amount of accessible potential energy contained in the timber design than the concrete design. With respect to process energy, there was relatively no difference between the concrete- and timber-framed alternatives (Figure 3b); meaning that approximately the same amount of energy was released throughout the production and operation of the industrial processes associated with the manufacture of the building materials in both design scenarios. The comparative values of fuel renewability (Figure 3a) also indicated that despite the timber-framed building having more associated cumulative EE, much more of this energy was derived from renewable sources. Recalling that the timber building design exhibited superior environmental performance in all but one impact category, yet demonstrated a much higher cradle-to-gate embodied energy total (feedstock and process), this particular LCA study has illustrated it is not accurate to directly correlate cumulative embodied energy results with potential environmental impacts-a conclusion that echoes past work [43].

\section{Future Research}

Additional research is required in order to improve the quality and comprehensiveness of the present study and other subsequent comparative LCA studies related to building construction systems. The accuracy of this study could be improved by using full-scale CLT manufacturing input data, along with refining the structural design calculations to include additional iterations. With respect to sustainability of the built environment, this comparison was based solely on environmental performance; in order to address the full scope of sustainable design and construction practices, an expansion of the analysis framework to include social and economic indicators is necessary. Tools such as social LCA, life cycle costing, and life cycle sustainability assessment are techniques that could be employed in order to expand the analysis of a building system comparison to include a more complete sustainable design ideology. The use of region specific and site specific environmental modeling refinements would also aid in depicting a clearer picture of the environmental implications that are relevant in the context of an individual region and building site. Predominantly, the data used was industry wide and averaged over the entire North American continent. A region-specific LCIA model, such as LUCAS [44] would be advantageous in identifying and quantifying parameters and environmental effects that are specific to Canada. Further research is also needed to identify and develop building product LCI data sets for other relevant environmental impact categories, such as soil salinity, erosion, habitat alteration, biodiversity loss, and land use impacts. This would aid in providing an even clearer picture of the comparative LCIA analysis. Furthermore, additional research related to the on-site construction phase and end-of-life scenarios is required in order to fill the knowledge gaps that exist regarding the impacts associated with these life cycle stages of a building. 


\section{Acknowledgments}

This research was made possible by the voluntary involvement of the following firms; CST Innovations Ltd., Reid, Jones, Christoffersen Consulting Engineers, and Bunting Coady Architects.

Appendix A: LCI data sources.

\begin{tabular}{ll}
\hline Building material & LCI data source \\
\hline Gypsum wall board & {$[12]$} \\
Steel stud framing & {$[12]$} \\
Wood stud framing & {$[12]$} \\
BioPreserve soyguard wood sealer & {$[12]$} \\
Anonymous R-13 insulation & {$[12]$} \\
Closed cell spray polyurethane foam insulation (ccSPF) & {$[45,46]$} \\
Slab-on-grade & {$[12]$} \\
Below-grade foundation walls \& spread footings & {$[12]$} \\
Above-grade concrete walls, beams, slabs, drop panels \& slab bands & {$[12]$} \\
Concrete columns & {$[12]$} \\
Cross-laminated timber walls \& floors & {$[10,47-49]$} \\
Glulam beams \& columns & {$[47,49,50]$} \\
Generic cedar siding & {$[12]$} \\
Curtain wall-vision glass \& spandrel & {$[51]$} \\
\hline
\end{tabular}

\section{References}

1. United Nations Environment Programme (UNEP). Buildings and Climate Change: Summary for Decision-Makers; UNEP Sustainable Building and Climate Initiative: Paris, France, 2009; pp. 2-11. Available online: http://www.unep.org/sbci/pdfs/SBCI-BCCSummary.pdf (accessed on 18 April 2012).

2. Natural Resources Canada. Mountain Pine Beetle; Natural Resources Canada: Ottawa, ON, Canada. Available online: http://cfs.nrcan.gc.ca/pages/49 (accessed on 18 April 2012).

3. Hamilton, G. Pine beetle epidemic to affect lumber supply continent-wide-interior sawmills are expected to start running out of good timber in 3 to 5 years. Vancouver Sun, 19 March 2010; Available online: http:/groups.yahoo.com/group/NatNews-north/message/17196 (accessed on 10 July 2012).

4. Ministry of Environment. British Columbia Greenhouse Gas Inventory Report 2007; Government of British Columbia: Nanaimo, BC, Canada, 31 July 2009; Available online: http:/www.bcsea.org/learn/ news/2009/07/31/british-columbia-provincial-greenhouse-gas-inventory-report-2007 (accessed on 16 July 2012).

5. Government of British Columbia. Residential Mid-Rise Wood-Frame Code Change; Government of British Columbia: Nanaimo, BC, Canada. Available online: http://www.housing.gov.bc.ca /building/wood_frame/ (accessed on 18 April 2012).

6. Junnila, S. Life cycle assessment of environmentally significant aspects of an office building. Nord. J. Surv. Real Estate Res. Spec. Ser. 2004, 2, 81-97.

7. Ortiz, O.; Castells, F.; Sonnemann, G. Sustainability in the construction industry: A review of recent developments based on LCA. Constr. Build. Mater. 2009, 23, 28-39. 
8. Martinsons. Massivträ Handboken (In Swedish); Martinsons: Bygdsiljum, Sweden, 2006.

9. Karacabeyli, E. Wood-Based Systems in Mid-Rise Construction; FP Innovations: Vancouver, BC, Canada, 2009.

10. Zaturecky, I.; Chow, M. CST (Canadian Sustainable Timber) Innovations Ltd., New Westminster, BC, Canada. Personal communication, 2009.

11. Bare, J.C.; Norris, G.A.; Pennington, D.W.; McKone, T. TRACI: The tool for the reduction and assessment of chemical and other environmental impacts. J. Ind. Ecol. 2003, 6, 49-78.

12. Lippiatt, B.C. BEES 4.0: Building for Environmental and Economic Sustainability, Technical Manual and User Guide; National Institute of Standards and Technology: Gaithersburg, MD, USA, 2007.

13. Finnveden, G.; Hauschild, M.Z.; Ekvall, T.; Guinée, J.; Heijungs, R.; Hellweg, S.; Koehler, A.; Pennington, D.; Suh, S. Recent developments in life cycle assessment. J. Environ. Manag. 2009, 91, 1-21.

14. Harvey, L.D. Handbook on Low-Energy Buildings and District-Energy Systems; Earthscan: Toronto, ON, Canada, 2006; p. 488.

15. Lenzen, M.; Treloar, G. Embodied energy in buildings: Wood versus concrete-reply to Börjesson and Gustavsson. Energy Policy 2002, 30, 249-255.

16. Lippiatt, B.C. BEES 4.0: Building for Environmental and Economic Sustainability, Technical Manual and User Guide; National Institute of Standards and Technology: Gaithersburg, MD, USA, 2007; p. 48.

17. Chen, J.Y. Development of Cross Lamination Technology for MPB Engineered Wood Products-Thick Laminated MPB Wood Plates; Technical Report for Forestry Innovation Investment Ltd.; University of British Columbia: Vancouver, BC, Canada, 31 March 2009.

18. Chen, Y. Structural Performance of Box Based Cross Laminated Timber System Used in Floor Applications. Ph.D. Dissertation, University of British Columbia, Vancouver, BC, Canada, 2011.

19. Wilson, J.B. Life-Cycle inventory of formaldehyde-based resins used in wood composites in terms of resources, emissions, energy and carbon. Wood Fiber Sci. 2010, 42, 125-143.

20. Werner, F.; Taverna, R.; Hofer, P.; Richter, K. Greenhouse gas dynamics of an increased use of wood in buildings in Switzerland. Clim. Chang. 2006, 74, 319-347.

21. International Panel on Climate Change (IPCC). 2006 IPCC Guidelines for National Greenhouse Gas Inventories; IPCC: Geneva, Switzerland, 2006.

22. Searchinger, T.D.; Hamburg, S.P.; Melillo, J.; Chameides, W.; Havlik, P.; Kammen, D.M.; Likens, G.E.; Lubowski, R.N.; Obersteiner, M.; Oppenheimer, M.; et al. Fixing a critical climate accounting error. Science 2009, 326, 527-528.

23. Cole, R.J. Building Materials in the Context of Sustainable Development; University of British Columbia: Vancouver, BC, Canada, 1994.

24. Hood, I.W. Energy and Economic Life-Cycle Analysis of an Office Building. M.S. Thesis, University of British Columbia, Vancouver, BC, Canada, 1995.

25. Cole, R.J.; Kernan, P.C. Life-Cycle energy use in office buildings. Build. Environ. 1996, 31, 307-317.

26. Kernan, P.C. Life-Cycle Energy Analysis of An Office Building. M.S. Thesis, University of British Columbia, Vancouver, BC, Canada, 1996. 
27. Canadian Wood Council (CWC). Comparing the Environmental Effects of Building Systems: A Case Study; CWC: Ottawa, ON, Canada, 1997; pp. 1-11.

28. Guggemos, A.A.; Horvath, A. Comparison of environmental effects of steel- and concrete-framed buildings. J. Infrastruct. Sys. 2005, 11, 93-101.

29. Krogmann, U.; Minderman, N.; Senick, J.; Andrews, C.J. Life-Cycle Assessment of New Jersey Meadowlands Commission Center for Environmental and Scientific Education Building; Edward, J., Ed.; The State University of New Jersey: New Brunswick, NJ, USA, 2008.

30. Krogmann, U.; Minderman, N.; Senick, J.; Andrews, C. Life-cycle assessment of a green educational building: A case-study. In Proceedings of Life Cycle Assessment IX Joint North American Life Cycle Conference: Toward the Global Life Cycle Economy, Boston, MA, USA, 29 September 29-2 October 2009.

31. Marcea, R.L.; Lau, K.K. Carbon dioxide implications of building materials. Int. J. For. Eng. 1992, $3,37-43$.

32. Gustavsson, L.; Joelsson, A.; Sathre, R. Life cycle primary energy use and carbon emission of an eight-storey wood-framed apartment building. Energy Build. 2010, 42, 230-242.

33. Cole, R.J. Energy and greenhouse gas emissions associated with the construction of alternative structural systems. Build. Environ. 1999, 34, 335-348.

34. Junnila, S.; Horvath, A.; Guggemos, A.A. Life-Cycle assessment of office buildings in Europe and the United States. J. Infrastruct. Sys. 2006, 12, 10-17.

35. Guggemos, A.A.; Horvath, A. Decision-Support tool for assessing the environmental effects of constructing commercial buildings. J. Archit. Eng. 2006, 12, 187-195.

36. TRADA Technology. Case Study: Stadthaus, 24 Murray Grove, London; TRADA Technology Ltd.: London, UK, 2009; pp. 1-7.

37. TRADA Technology. Case Study: Kingsdale School, London; TRADA Technology Ltd.: London, UK, 2008; pp. 1-6.

38. O'Connor, J. Survey on actual service lives for North American buildings. In Proceedings of the Woodframe Housing Durability and Disaster Issues, Las Vegas, NV, USA, 4-6 October 2004.

39. National Trust for Historic Preservation. New Energy from Old Buildings; The Preservation Press: Washington, DC, USA, 1981.

40. Engineering, M.G. Demolition Energy Analysis of Office Building Structural Systems; The ATHENA Sustainable Materials Institute (ASMI): Ottawa, ON, Canada, 1997.

41. Müller, C. Design for recycling using concrete and masonry as an example. In Integrated Life Cycle Design of Structures; Sarja, A., Ed.; Spon Press: New York, NY, USA, 2002; pp. 81-96.

42. Langer, W. Sustainability of aggregates in construction. In Sustainability of Construction Materials; Khatib, J.M., Ed.; CRC Press: Boca Raton, FL, USA, 2009; pp. 1-30.

43. Svensson, N.; Roth, L.; Eklund, M.; Martensson, A. Environmental relevance and use of energy indicators in environmental management and research. J. Clean. Prod. 2006, 14, 134-145.

44. Toffoletto, L.; Bulle, C.; Godin, J.; Reid, C.; Deschênes, L. LUCAS-A new lcia method used for a canadian-specific context. Int. J. Life Cycle Ass. 2007, 12, 93-102.

45. Krähling, H.; Krömer, S.; Mersiowsky, I. High Performance Thermal Insulation for Buildings in Spain and Portugal: Life Cycle Assessment on HFC-365mfc-blown rigid Polyurethane Sprays; Report for Solvay Management Support: Hannover, Germany, 2001. 
46. Harvey, L.D. Net climatic impact of solid foam insulation produced with halocarbon and non-halocarbon blowing agents. Build. Environ. 2007, 42, 2860-2879.

47. Puettmann, M.E.; Wilson, J.B. CORRIM: Phase I Final Report, Module G, Glued Laminated Beams-Pacific Northwest and Southeast; Oregon State University, Corvallis, OR, USA, 2004; p. 85; Available online: http://www.corrim.org/pubs/reports/2005/phase1/Module_G_Final.pdf (accessed on 5 July 2012).

48. Athena Sustainable Materials Institute (ASMI). A Cradle-to-Gate Life Cycle Assessment of Canadian Softwood Lumber; FP Innovations: Vancouver, BC, Canada, 2009.

49. United States Life Cycle Inventory Database. Available online at: http://www.nrel.gov/lci/ (accessed on 15 May 2009).

50. Puettmann, M.E.; Wilson, J.B. Gate-to-gate life-cycle inventory of glued-laminated timbers production. Wood Fiber Sci. 2005, 37, 99-113.

51. ATHENA ${ }^{\circledR}$ EcoCalculator for Assemblies, Version 2.3; Athena Sustainable Materials Institute: Ottawa, ON, Canada, 2009.

(C) 2012 by the authors; licensee MDPI, Basel, Switzerland. This article is an open access article distributed under the terms and conditions of the Creative Commons Attribution license (http://creativecommons.org/licenses/by/3.0/). 